\title{
The Case for Permanent Residency for Frontline Workers
}

\section{MOLLIE GERVER University of Essex, United Kingdom}

\begin{abstract}
7 his article presents the case for granting permanent residency to those experiencing significant risks throughout the COVID-19 pandemic to increase citizens' safety. Increasing safety comes in many forms: directly, as when doctors, paramedics, and nurses assist patients, and indirectly, as when farmworkers produce life-sustaining food, garbage collectors protect sanitation, and social workers respond to emergency calls. A range of such workers are owed gratitude-derived duties from citizens that are best fulfilled via permanent residency. I defend this claim first for authorized migrants and then for unauthorized migrants, whose presence citizens would consent to if they were aware of the benefits they provide. Finally, I defend the claim that many frontline workers not owed gratitude are owed duties of justice, acquiring rights similar to those of permanent residency.
\end{abstract}

\section{INTRODUCTION}

D uring the spread of COVID-19, Nancy Silva was picking clementines in California, cognizant of her close proximity to coworkers. This close proximity, experienced by tens of thousands of agricultural workers in California, meant she was roughly three times more likely to become infected than the average American. Ms. Silva continued despite these risks, grateful for the temporary visa provided for her efforts, as part of temporary reforms to protect food security during the pandemic (Jordan 2020; Villarejo 2020).

A similar reform was instituted in the UK for medical workers, with year-long visa extensions offered to National Health Service (NHS) employees. More recently, a coalition in the U.S. Congress proposed green cards to 40,000 nurses and doctors, and a coalition in the UK parliament proposed permanent residency to all NHS staff (Economic Times 2020; Siddique 2020). Some have called for permanent residency for all on the front line, including sanitation and agricultural workers. As one op-ed writer explained, it's "the least we can do ... in repayment for their service and sacrifices" (Moran 2020).

This article presents the case for granting permanent residency to frontline workers, defined here as those experiencing substantial risks throughout the pandemic to substantially increase citizens' safety. Increasing safety comes in many forms: directly, as when doctors and nurses assist patients, and indirectly, as when farm workers produce life-sustaining food, garbage collectors protect sanitation, and social workers respond to emergency calls. ${ }^{1}$

Mollie Gerver (D), Assistant Professor, Department of Government, University of Essex, United Kingdom, m.gerver@essex.ac.uk.

Received: August 19, 2020; revised: January 30, 2021; accepted: June 17, 2021. First published online: July 26, 2021.

\footnotetext{
${ }^{1}$ While some such individuals are not termed "frontline workers" by all governments, so long as individuals face substantial risks in
}

I initially present a gratitude-based case for permanent residency for frontline workers. The first section presents a general theory of gratitude; I then demonstrate how gratitude can ground rights to permanent residency for a range of authorized frontline migrants. Following this, I argue that the gratitudebased case applies to unauthorized migrants who have citizens' "hypothetical consent." This refers to frontline workers whom citizens would consent to working if aware of the benefits such migrants provide.

In drawing on the value of gratitude, this article relies on a value yet to be fully articulated within broader ethical debates on immigration. These broader debates focus on alternative values, including: reciprocity, where migrants' contributions ground the right to permanent residency (Shachar 2009; Song 2018; Sullivan 2019; Rubio-Marin 2000); membership, where migrants' interactions with citizens ground the right to permanent residency (Carens 2013; Shachar and Hirschl 2014); and equality, where migrants' vulnerability grounds the right to permanent residency (Berg 2016; Lenard and Straehle 2010; Walzer 1983). In the second half of this article, I demonstrate that these alternative values ground rights to permanent residency for many frontline workers who lack gratitude-based grounds, with the value of equality particularly apt at demonstrating that unauthorized migrants lacking citizens' hypothetical consent would be exploited if denied permanent residency. However, these values do not apply to many frontline workers who do have gratitude-based grounds. In this sense, gratitude remains essential for a complete understanding of frontline workers' rights.

The final two sections argue that gratitude is essential for immigration ethics more generally. Firefighters, soldiers, and even nurses who work night shifts often assume substantial risks while helping citizens (Vetter et al. 2016), as do some nonmigrants abroad. I argue that the duty of gratitude implies that high-income states

reducing risks for citizens, they have grounds for obtaining permanent residency. 
have a duty, beyond COVID-19, to increase the number of individuals who are granted permanent residency.

\section{A THEORY OF GRATITUDE FOR RISK-TAKERS}

This section describes a theory of gratitude for one individual benefiting from another, followed by a theory of gratitude for one group benefiting from another.

\section{Two-Person Cases}

Humans generally owe gratitude to those they benefit from, especially when those they benefit from risk their lives. More specifically, a beneficiary owes gratitude to a benefactor when

1. the benefactor freely assumes life-threatening risks to increase the beneficiary's odds of survival;

2. the benefactor's intention is not merely to strategically and personally gain from the beneficiary;

3. the beneficiary has no right that the benefactor take on risks she assumes; and

4. the beneficiary has consented, or would have consented if possible, to the benefactor assuming risks.

These conditions are not all necessary for owing gratitude, but they are jointly sufficient. ${ }^{2}$ For example, imagine Beatrice dives into the ocean to save Charles, who is drowning, because she cares about him. Imagine, also, that Charles holds no right to being saved given life-threatening risks for Beatrice, but would have consented to being saved if asked. It seems he owes her gratitude.

In demonstrating gratitude, Charles should not provide money alone. He should not arrive on shore, hand over $£ 100$, and walk away without a word. This would imply that their relationship is not one between a human risking her life for another, but of one human merely transacting with another.

To express gratitude for the risks she assumed, he ought to tell Beatrice that he appreciates what she did (Camenisch 1981; Von Tevenar 2006) and demonstrate concern for her welfare, given how much she has done for his. He should ask how she is fairing, having just risked her life. Moreover, given how high the stakes were, he should continue inquiring into her welfare without some specified end-date. He should not ask how she is once, and then ignore her if they run into each other, or say, "I will inquire into your welfare for one year, after which my duties to inquire into your welfare have been exhausted." Such an expiration date fails to demonstrate that their relationship is not what it was prior to her saving him, given the risks she undertook.

If he ought to demonstrate concern, he ought to additionally offer to keep some line of communication

\footnotetext{
${ }^{2}$ This is consistent with a range of theories of gratitude (Manela 2015; Simmons 1981; Walker 1980).
}

open so that such demonstrations are possible. While he needn't forever inquire into her welfare, he should not block her on social media, refuse to take her calls, and walk down a different street to avoid talking with her. In other words, he ought to at least keep some passive line of communication open.

Importantly, to demonstrate concern for Beatrice's welfare he should take actions that protect this welfare. He should avoid welfare-reducing harm that would otherwise be permissible, and provide welfareenhancing aid that would otherwise be supererogatory (Manela 2015; Terrance 1993; Walker 1980). More specifically, he ought to avoid harm and provide aid with certain characteristics.

One characteristic concerns costs: aid owed in gratitude needn't exceed an upper threshold of costs. For example, if Beatrice needs a ride to the hospital, or lacks money for one month's rent, Charles ought to help if costs fall below a threshold that is higher than the threshold for someone who never risked her life for his, all else being equal. While he needn't donate a kidney, he might need to donate some of his time and money (Hartley 2014; Von Tevenar 2006).

The same likely holds true for harm avoidance. Imagine Charles and Beatrice own competing cafes, and Charles can harm Beatrice by telling customers how unimpressive her coffee is. He should avoid doing so if costs for him fall below a given threshold (perhaps experiencing only a modest reduction in profits), but might still be permitted to criticize her coffee if necessary for keeping his business afloat. While the precise threshold of costs is debatable, the costs are higher than had Beatrice never risked her life for his, but not without limit.

There is a second characteristic to welfare protection for gratitude: even if aid and harm-avoidance are only obligatory until a given threshold of costs, this threshold does not dissipate with time, at least when owing gratitude for surviving. Imagine Beatrice only asks for help 20 years later, lacking sufficient nutrition. Charles should not respond, "I owe you nothing, because 20 years have passed since you saved my life." If 20 years have passed, Charles has now lived 20 years because of Beatrice. While total obligatory assistance over 20 years is limited to some threshold-perhaps he needn't buy her food every month for 20 years - this threshold has no expiration date, because the passage of time increases rather than diminishes benefits for Charles.

A final characteristic concerns competing considerations. Charles needn't protect Beatrice's welfare if he has weightier moral reasons to protect others instead, holding an all-things-considered duty to help them instead of her. If Beatrice needs money for one month's rent, Charles is not obligated to pay this rent if another individual to whom he has a duty to help requires money to survive, and Charles can either help them or Beatrice.

In short, a beneficiary owing gratitude to a benefactor for risking her life ought to:

1. express concern over her welfare when running into her, 
2. keep at least passive modes of communication with her open, and

3. protect her welfare by avoiding harm and providing necessary aid that

(a) costs equal to or less than a given threshold,

(b) does not expire at a given point, and

(c) does not clash with a competing and weightier reason to protect the welfare of another agent instead.

The above concerns cases where a benefactor has no obligation to risk her life. Some claim gratitude is not owed toward those with a duty to save others, particularly when those saved have a correlative right to be saved (Callahan 1982; Heyd 1982). Imagine Beatrice is a lifeguard with a duty to save others and with Charles having a right to be saved.

Even if no duty of gratitude is owed in such cases, a duty of gratitude would be owed if Beatrice took risks beyond those her professional duties demanded, in that she would not be blameworthy for avoiding such risks. A lifeguard may have a duty to assume more risks than nonprofessionals, but needn't assume substantial risks to her life; lifeguards undergo training precisely to ensure risks during rescues are lower than those nonprofessionals would typically assume if engaging in similar rescues. If Beatrice's risks are not substantially reduced from her training-perhaps there is a major storm - she likely has no duty to take on such risks. If she does nonetheless, Charles owes her gratitude.

If gratitude is owed for risks that are supererogatory for a profession, someone can be owed gratitude even if not risking her life in a biological sense. An individual might risk losing the life she once lived, including her ability to realize important life projects or conceptions of the good. When this risk is supererogatory, a similar duty of gratitude is owed. ${ }^{3}$ If Beatrice would unlikely die, but be exposed to dyspnea-causing cyanobacteria in the water - constraining her ability to pursue important life goals-Charles would owe her a duty of gratitude.

At least, it seems he would owe her gratitude if she freely exposed herself to risks. Imagine this wasn't the case, and she saved Charles to avoid being fired by her employer and destitute. Some might feel she would be wronged by her employer, but not owed gratitude from Charles. This is because some claim those coerced into assistance are not owed gratitude: if X puts a gun to Y's head and tells her to risk her life to save Z's, Z may appreciate Y saving him, but owes her no gratitude (Simmons 1981; McConnell 2017). While nobody is putting a gun to Beatrice's head, her employer's threat may have dire consequences, and so constitute coercion, undermining any gratitude owed by Charles.

In such cases, while no gratitude is owed if Beatrice takes risks solely because of her employer's threat, if her motivation is not this threat-she just cares about helping those drowning-Charles owes her gratitude. Though she was subject to coercion, she took risks not

\footnotetext{
${ }^{3}$ Thanks to an anonymous reviewer for raising this point.
}

because of coercion, but out of concern for his life. If she took risks out of concern for his life, Charles ought to demonstrate concern for hers, and fulfil the usual duties of gratitude.

This raises the question of what should be done when it is not clear if someone is motivated by coercion. There are good reasons to presume someone is not motivated by coercion if they claim they are not, and establishing if this is true would itself violate duties of gratitude. If Beatrice faces coercion but is motivated only by concern for Charles, and Charles asks her to answer a battery of questions to deduce her motives before demonstrating gratitude, such interrogation might be particularly psychologically harmful. If enough harm is incompatible with duties of gratitude, the interrogation may itself violate duties of gratitude.

Moreover, such interrogation may be wrongful for reasons independent of gratitude-based duties. If it seems likely Beatrice saved Charles only to avoid being fired and destitute, interrogating her in particular may be wrongfully discriminatory. Wrongful discrimination, it is broadly accepted, occurs when disadvantaged groups are treated in a demeaning or worse-off manner in virtue of being worse-off already (Hellman 2008; Lippert-Rasmussen 2014). Such discrimination may arise when claiming some workers' desperate circumstances are evidence that their motives for taking risks are not to help others. If a subset of lifeguards had few other choices of profession, and it was assumed they were not motivated by concern for those saved, interrogating only their motives would be wrong. If they claim they are not motivated by the threat of being fired and destitute, there are good reason to take them at their word.

There remain cases where an individual is clearly assuming risks just to avoid being fired and destitute, admitting to this fact or never claiming otherwise. In such cases, no gratitude is owed. Instead, duties of justice are owed, derived from potentially exploitative contracts; Beatrice is exploited if risking death or dyspnea to avoid destitution from unemployment. Like with gratitude, special duties are owed to such individuals beyond giving money. I defend this claim in the second half of the article.

For now, we can at least conclude this: agents assuming supererogatory risks to save others, and doing so freely or claiming coercion is not their motivation, ought to be shown gratitude.

\section{Groups}

The above focuses on two-party cases. Gratitude is also relevant for groups. If Charles ought to demonstrate gratitude when Beatrice assumes undue risks to help him survive, a group of individuals ought to demonstrate gratitude toward another group, if each member of the latter group assumes undue risks to substantially increase survival odds for all members of the group benefiting. At least, they ought to be shown gratitude if they take risks freely, or to help beneficiaries. For example, imagine many lifeguards sail out to save many drowning at sea, freely taking risks above those 
required of their profession. Each lifeguard engages in nontransactional assistance, given that she goes beyond the professional obligations of her contract. This is true even if she does not personally increase any individual's odds of survival a great deal, merely being part of a group substantially increasing such odds. If she engages in nontransactional assistance, she is owed gratitude not reducible to a transfer of money.

Based on this reasoning, gratitude can even be owed by beneficiaries never needing help. Consider lifeguards taking supererogatory risks in a town where all residents swim. If most residents never end up needing assistance, but would obtain assistance if the need arose, and they have even moderate chances of the need arising, everyone's survival odds can increase significantly. If they have a $1 / 100$ chance of drowning without a lifeguard, but a 1/3,000 chance with a lifeguard, lifeguards being willing and actually taking supererogatory risks significantly increases residents' odds of survival. If such residents consent to lifeguards taking on supererogatory risks in saving anyone needing help, they owe gratitude even if never saved.

The same conclusion arises when different professionals assume risks. Consider a town with not only lifeguards, but firefighters risking their lives in burning buildings, and social workers risking their lives responding to domestic violence. Even if a given resident never requires a lifeguard, firefighter, or social worker, the risks all workers assume mean any resident will be assisted if the need arises. The more life-saving workers there are, the more safe a given resident is. If residents' risks are substantially reduced because of these workers' supererogatory risks, residents owe them gratitude.

Note that this argument does not appeal to controversial claims about group duties. Some claim that groups like polities can have duties not reducible to the duties of each group member (Collins 2019; Hindriks 2018). My claim is more modest: individual group members, where each member benefits, each owe gratitude to all members of a second group, when each member of the second group personally takes on morally nonobligatory risks, collectively reducing risks for each member of the first group. If each member of the first group owes gratitude, they ought to demonstrate concern for each member of the risk-taking group, including keeping some type of communication with them open, and protecting their welfare.

At least, protecting welfare is obligatory if costs fall below a given threshold. Here, group cases diverge from two-person cases. While in two-person cases there is some upper threshold of costs the beneficiary must bear depending on his circumstances, in group cases the threshold varies between beneficiaries depending on their circumstances relative to each other. This is because of general principles of fairness.

Principles of fairness - outside the scope of gratitude alone-hold that responsibility allocation ought to account for relative privileges. For example, the wealthy generally must contribute more than others in helping individuals in need, and a given wealthy person's obligatory costs may be greater the fewer other wealthy individuals there are. It is also broadly accepted that duties can arise because of others' failure to do their fair share, as when the wealthy ought to end global poverty on their own, do not, and the middleclass ought to "take up the slack" and contribute some resources (Karnein 2014; Stemplowska 2016). Applying these theories to the lifeguards above, if a lifeguard is in grave need, and gratitude requires that she receive assistance from beneficiaries of her supererogatory risks, wealthy beneficiaries are likely required to bear greater costs in helping her compared to poor beneficiaries, with the upper costs anyone is required to bear varying depending on the wealth distribution amongst beneficiaries, and whether cobeneficiaries do their fair share; if wealthy beneficiaries unfairly refuse to help, middle-class beneficiaries might be required to give a little more. Fairness applies to benefactors as well: the welfare a benefactor is entitled to obtain varies depending on how well-off other benefactors are. For example, if years pass and no lifeguards need help, except one requiring costly cancer treatment, perhaps beneficiaries should pay for her treatment, but not if all lifeguards require this treatment, such that total costs would exceed the obligatory threshold for demonstrating gratitude.

\section{GRATITUDE TO FRONTLINE WORKERS}

The above theory has far-reaching implications for frontline workers. This section focuses on implications for frontline workers with certain characteristics. The first two characteristics, to be removed in the next two sections, are that the workers are authorized to work in the country, and assuming risks that citizens have or would consent to being assumed on their behalf. In other words, just like someone benefiting from lifeguards cannot necessarily consent to lifeguards' assistance, but would consent if asked, citizens cannot necessarily consent to frontline workers' actions, but would consent if asked. This is a reasonable assumption for most authorized frontline migrants, given widespread public support for frontline workers' actions (Ballinger 2020).

A third characteristic is that the workers are taking risks beyond those morally required of their profession, as when health care workers suddenly find themselves at risk of dying from COVID-19, or experiencing "Long-COVID," including extreme fatigue and damaged lungs (Logue et al. 2021).

I further assume, and will continue to in the next section, that the workers would (a) not be fired and destitute if refusing to take risks or (b) even if they would, they claim to be motivated by concern for others and (c) establishing if they speak truthfully would be wrong for reasons described in the last section. For example, a nurse might be fired and deported to a poor country if refusing to take risks, but claim to be assuming risks solely to help patients. Similarly, an agricultural worker might be destitute if she didn't work, but claim she takes risks to ensure food security for citizens, rather than fear of destitution. Even if these workers 
are potentially lying, it would seem wrong to interrogate them to establish their motives. This would likely cause harm that violated duties of gratitude and nondiscrimination: if harming already-disadvantaged individuals is often wrongfully discriminatory, as argued in the last section, it might be wrongfully discriminatory to interrogate workers because of their extremely constrained options.

Finally, I assume that the workers in question collectively and substantially increase most citizens' survival odds. Some do so by slowing the disease's spread, reducing citizens' odds of infection, as when delivery drivers reduce citizens' congregation in shops. Others decrease risks by providing necessary help as described in the last section. For example, health care workers ensure citizens can receive medical care if the need arises, even if they never need this care. This is true not only for COVID-19 treatment: nurses, doctors, and technicians risking their lives during a pandemic help with a range of life-risking medical conditions. If healthcare substantially increases most citizens' odds of survival, including citizens never requiring care, then health care workers facing risks during a pandemic collectively and substantially increase most citizens' odds of survival.

The same holds true for workers contributing to general safe environments. Garbage collectors risk their lives during a pandemic to ensure sanitation that (pandemic or not) increases citizens' odds of survival, and agricultural workers risk their lives during a pandemic to ensure food security that (pandemic or not) increases citizens' odds of survival (FAO 2020). Importantly, all three-health care, sanitation, and agricultural workers - contribute to even greater combined increases in citizens' survival odds.

If most citizens experience substantially increased survival odds because of these frontline workers' contributions, and each worker experiences risks above those morally required of their profession (and does so freely or presumably to help citizens), citizens owe them duties of gratitude. This requires demonstrating concern for frontline worker's welfare, keeping some type of communication with workers open, and protecting workers' welfare.

This raises the question of how concern, communication, and protection are implemented. Implementation challenges were largely put aside in last section's discussion, but highly relevant when very large groups benefit from other very large groups. Given this feature of frontline worker assistance, citizens cannot and ought not directly demonstrate gratitude in the way that Charles demonstrates gratitude to Beatrice.

This is for multiple reasons. One relates to privacy: imagine a nurse opening her door to find millions of thankful citizens offering to stay in touch and provide any assistance she needs. The offer might violate her privacy, as would requiring her to tell crowds of wellintentioned citizens whenever she was in dire need. Even if privacy were ensured, there would be epistemic barriers: a given citizen rarely knows who saved his life, given the collective and/or indirect nature of frontline assistance. If he passes a former frontline worker living on the street, he will not know whether he benefited from her, or if she was a frontline worker at all. There would be related coordination problems. With potentially millions of frontline workers, the diversity of needs would not be conducive to isolated acts of kindness found in two-party cases.

Epistemic and coordination problems can additionally create problems concerning fairness. If establishing one's personal duties of gratitude requires establishing one's relative wealth, and whether others are doing their fair share, each beneficiary would struggle to independently establish their specific obligations. It would be difficult for each citizen to know how welloff she was compared to others, what others were doing, and what beneficiaries needed, and so difficult to know what costs she must bear and to whom she must bear these costs.

There is a final problem relating to control, particularly applicable to migrants. As noted in the last section, gratitude requires avoiding harm entailing belowthreshold costs. Citizens often contribute to harms of frontline worker migrants. This is because citizens pay taxes supporting immigration enforcement, including border officers engaging in extreme violence during deportation (Carens 2013; Lister 2020; Sager 2017). Even when violence is avoided, taxes contribute to visceral psychological pain workers might experience if instructed to leave the state where they risked their lives for others. If showing gratitude requires avoiding some harm, but citizens lack control over harms they contribute to, it is difficult for citizens to control their ability to show gratitude.

Given epistemic, privacy, coordination, and control barriers for citizens, this poses problems for the state as a whole. This is because the state and its institutions have moral reasons to ensure that citizens can fulfil their duties in general, at least when these duties are held by most citizens and especially weighty (Quong 2010; Raz 1988; Tadros 2016). If citizens' duties of gratitude toward frontline workers are especially weighty, states ought to institute policies helping citizens fulfil these duties. They should therefore help citizens avoid the epistemic, privacy, coordination, and control barriers toward fulfilling these duties.

There are good reasons to suppose the policy most conducive to overcoming the four barriers is granting permanent residency to frontline workers. By "permanent residency" I mean visas permitting frontline workers to

1. work in the state without being deported,

2. engage in public communicative acts, such as protesting and raising court petitions, and

3. obtain access to essential welfare provisions, including unemployment benefits, education, and public housing for those in need. ${ }^{4}$

\footnotetext{
${ }^{4}$ In countries where only citizenship brings about protection from deportation, the right to publicly communicate, and access to welfare provisions, frontline workers ought to be granted citizenship. In other words, I use "permanent residency" as shorthand for a status incorporating the above three aspects.
} 
Each aspect helps citizens fulfil their duties of gratitude. The first (1) ensures citizens avoid contributing to harms via deportation. In theory, of course, states could engage in deportation while ensuring citizens fulfill duties of gratitude, by ensuring harms from deportation were minimized, up until costs of avoiding harm fell below the obligatory threshold for duties of gratitude. While this is theoretically possible, individual enforcement agents widely ignore official state policies, even when legislatures introduce more humane policies (Sager 2017). This leads to disproportionate harms in general (Lister 2020). If harms are disproportionate in general, they are disproportionate for agents owed gratitude, given that harm permitted against those owed gratitude is less than harm permitted against those not owed gratitude (all else being equal). For states to ensure citizens are not contributing to impermissible harm, thus ensuring citizens fulfil their duties of gratitude, states ought to grant permanent residency to frontline workers.

The second aspect (2) refers to public actions that are directed at capturing the public's attention, including protesting, striking at work, talking to reporters, approaching policymakers, organizing community meetings, and appealing to neighbors and friends. The opportunity to pursue these actions helps citizens and migrants communicate on a public level, even when personal communication is not possible or desirable. More specifically, migrants pursuing such actions while they are physically present in the state can more effectively gain citizens' attention (Beltran 2009; GloashBoza 2014), such that citizens can more easily express concern in response. Once deported, electronic communication-Zoom and blogs-are thin alternatives for frontline workers communicating with citizens, and for citizens demonstrating concern by communicating back. ${ }^{5}$

The above explains why being physically present is important for harm-avoidance and communication. It does not explain why frontline workers should access (3), essential welfare provisions. Many frontline workers come from countries offering essential provisions, and can return to their home countries if in need. While this may be true, if frontline workers must leave their country-of-residence to obtain such provisions, they will be unable to engage in public communicative acts that help citizens fulfil their duties of gratitude. Moreover, being unable to access aid in the country where they risked their lives diminishes citizens' ability to demonstrate gratitude. Just like Charles fails to demonstrate gratitude if he is unwilling to provide aid to Beatrice, even if Beatrice never needs this aid because another individual will provide it instead, citizens fail to demonstrate gratitude if they are unwilling to provide

\footnotetext{
${ }^{5}$ I presume frontline workers would also eventually have a right to citizenship, including voting rights, further empowering them to communicate with citizens on a public level. However, gratitude may be insufficient for citizenship rights until frontline workers have lived a minimal number of years in the country. Those frontline workers who have already lived in the country for a given number of years are likely owed citizenship.
}

aid to frontline workers, even if workers never need this aid because another state will provide it instead. By ensuring welfare provisions, citizens communicate a willingness they otherwise do not communicate, thus demonstrating gratitude they otherwise do not demonstrate.

Some might suppose that, though permitting continued residency while obtaining assistance is necessary, usual welfare provisions are not. States could just send a large one-off check equal to the maximum owed to frontline workers.

While such a check might seem sufficient, there are good reasons for citizens to instead provide welfare as needs arise. As noted, when many benefactors are owed gratitude, the upper costs they are entitled to vary depending on cobenefactors' needs, as when only one lifeguard needs expensive cancer treatment, versus all needing such treatment. Because needs change across time, it can be difficult to know the help a given benefactor is entitled to at a given time. Providing frontline workers help based on need (as with normal welfare provisions) avoids scenarios where some are given money not covering important needs, while others are denied help to cover important needs.

There is a related problem with a one-off check. As noted with Charles, a beneficiary needn't provide aid to a benefactor if then unable to help someone he has weightier competing reasons to help instead. States can account for this consideration by providing aid as needs arise. For example, if a state could provide housing to homeless frontline workers, but has weightier reasons to provide cancer treatment to nonfrontline-workers, and it can afford to provide either housing or cancer treatment, it ought to provide the latter alone. It fails to do so if preemptively handing out checks covering housing frontline workers might later need; the state cannot easily take back the checks if later learning that a more pressing duty has arisen. To systematically weigh competing considerations, workers should be subject to a welfare policy, rather than a one-off check.

Even if one rejects this conclusion, one can at least accept this: if frontline workers are not given a large check equal to the minimum threshold owed, they have grounds for not only permanent residency, but welfare provisions equaling or above this threshold.

The argument thus far focuses on migrants, but it seems citizen frontline workers assuming supererogatory risks are also owed gratitude. This poses a problem: when frontline migrants and citizens assume similar risks, it is not clear why frontline migrants are given a distinct benefit of permanent residency. Put another way: if permanent residency for frontline migrants is a substantial benefit compared to their current circumstances, while citizen frontline workers are not given such a substantial benefit compared to their current circumstances, citizens would be provided fewer gratitude-based benefits relative to their current circumstances. This seems inconsistent.

One response is to reject the claim that, when multiple individuals are owed similar gratitude, benefits owed must be similar as well. If Beatrice is Charles' wife, already owing her assistance should she find 
herself in need, his duties of gratitude might not generate new duties of assistance. In the original case where Beatrice is not his wife, he does owe her assistance he otherwise would not, but this is consistent; sometimes a reason one owes certain goods can be overdetermined for some and not others, such that some and not others will gain new benefits when taking on comparable risks. Citizen frontline workers are already owed permanent residency, so they would benefit less than frontline workers, but this is consistent with the claim that frontline workers are owed gratitude-based permanent residency.

There is a second potential reason migrants are owed permanent residency, even if many citizen take on similar risks: the risks migrants face may be farther from baseline risks they have duties to accept. For example, even if no nurse is morally obligated to assume a 1/100 chance of dying, citizen nurses might still be obligated to assume greater risks than migrant nurses, such that when a migrant and citizen both assume a 1/100 chance of dying from COVID-19, the difference between the migrant's risks and her obligatory baseline is greater than the difference between the citizen's risks and her obligatory baseline. If risks migrants assume are farther from their obligatory baseline, granting them permanent residency is justified even if citizens' gratitude-based benefits are not as great compared to their current circumstances.

Why might citizens have a higher obligatory baseline? Perhaps citizenship confers benefits, and benefits create duties - such as the duty to take on risks - not held by nonbeneficiaries (Moore 2009). Alternatively, perhaps citizens have duties to assume greater risks to show solidarity to conationals. Such solidarity might be intrinsically valuable, or valuable when encouraging the fulfilment of certain cosmopolitan goals (Brock 2002; Hurka 1997; Moore 2009; Seglow 2013). If citizens have a duty to assume more risks, this could justify granting special benefits to migrants in virtue of risks migrants assume.

If special benefits are warranted, and so permanent residency justified, this would have implications in a range of countries. The Canadian and French governments have already announced the granting of permanent residency for some frontline workers. Up to 50,000 can qualify in Canada, and though only 700 have qualified so far in France (Government of Canada 2021; Méheut 2020), far more have moral grounds for remaining permanently, including some of the roughly 276,000 agricultural workers in the country (AugèreGranier 2021). While those taking risks to avoid destitution are not owed gratitude-based permanent residency, those taking risks freely or to help others are. The same applies to some or all of the approximately 200,000 agricultural workers in the US on H-2A visas (Flocks 2020), approximately 200,000 agriculture workers in Italy on six-months visas (Isaac and Elrick 2020), and 40,000-80,000 seasonal agricultural workers in the UK. ${ }^{6}$ It would additionally apply to potentially all

\footnotetext{
${ }^{6}$ This is a broad estimate, but there is no broadly accepted precise number. See Department of Environment, Food, and Rural Affairs
}

29,010 health care workers in the UK given temporary visas between 2017 and 2019 (Sumption and Kierans 2019), and approximately 25,500 health care workers in the US on H1-B visas or without Green Cards (Painter 2020).

\section{UNAUTHORIZED MIGRANTS}

While implications for many authorized migrants are clear, implications for unauthorized migrants are not. This is because gratitude-based arguments presumed consent: citizens would consent to risks frontline workers assume, and so the consent condition for gratitude is met. This assumption may be untrue for migrants without visas, including over five million agricultural workers in the US (Budiman 2020; Dudley 2020) and roughly 100,000 in Italy (D'Ignoti 2020; Isaac and Elrick 2020). While citizens might consent to such workers tacitly-for example, Brock $(2020,96)$ and Rubio-Marìn (2000, 83) suggest citizens tacitly consent to undocumented workers if knowingly benefiting from their work and raising no opposition-this is controversial. It is controversial to claim that knowingly benefiting and not opposing are sufficient for tacit consent (Pevnik 2011, 167; Song 2018, 182-3). Even if they are, most citizens might not knowingly benefit from unauthorized frontline workers. They might therefore give neither tacit nor "hypothetical consent"; if asked, they would not consent to unauthorized workers picking fruit or collecting waste.

Even if citizens would not consent if asked in a simple manner, they might still consent in a world where other conditions were different. More specifically, they might give hypothetical consent in two ways:

1. Citizens might consent if given information on risks frontline workers face and benefits they provide and

2. Citizens might consent if they did not hold xenophobic views.

In what follows, I demonstrate that circumstance (1) is sufficient for fulfilling the consent condition for gratitude, but not necessarily circumstance (2). However, in both circumstances, and even when citizens would not consent with full information and no xenophobia, gratitude may still be owed when frontline workers cannot reasonably know what citizens would consent to if asked.

To defend the first claim - that the consent condition of gratitude is fulfilled in case (1) - I begin with a premise concerning autonomy: a benefactor assuming supererogatory risks is owed gratitude if respecting the beneficiary's autonomy. This is why it matters that Charles would have consented to Beatrice saving his life if asked: it matters that Beatrice is saving Charles' life in a manner that he autonomously desires, rather than against his wishes. If so, this raises the question of

(DEFRA) 2020a; 2020b and Environment, Food, and Rural Affairs Committee (EFRAC) 2020. 
what sort of hypothetical consent indicates that autonomy is respected.

A recent theory of consent sheds light on this question. According to David Enoch, hypothetical consent protects autonomy if features removed in the hypothetical scenario are not features the consent-giver endorses and views as part of their identity (Enoch 2017).

For example, imagine Charles would not have consented to being saved if asked because he has strongly endorsed religion commitments that prohibit being saved. In a hypothetical world where he lacked these commitments, he would consent to being saved. This sort of hypothetical consent does not indicate that saving Charles respects his autonomy. For, in a world where he did not hold these commitments, an important aspect of his identity would be different. Saving him based on this hypothetical world would not be respecting the autonomy of Charles in this world. In contrast, imagine that Charles would not have consented to Beatrice saving his life if asked because he is temporarily confused and thinks Beatrice can't swim, but would have consented if he knew Beatrice could swim. It seems Beatrice ought to save his life, assuming believing Beatrice cannot swim is not central to his self-conception. Saving him would respect his autonomy, and not the autonomy of some distant variant of Charles.

The above has implications for gratitude. Not only does Beatrice respect Charles' autonomy by saving him if he would consent when aware she can swim; it seems Charles owes her gratitude, given that he benefited whilst having his autonomy respected.

This, in turn, has implications for frontline workers. If citizens are unaware of frontline migrants's assistance and risks they assume, citizens are unlikely to view their ignorance as essential to their identities. If they don't, removing this ignorance in the hypothetical scenario, and then asking what citizens would consent to in this scenario-in other words, asking if they would consent if given accurate information - is the right sort of question for establishing whether migrants are respecting citizens' autonomy. If citizens would consent to undocumented migrants working if aware of risks assumed and contributions provided, these workers respect citizens' autonomy. If undocumented workers assume supererogatory risks while respecting citizens' autonomy, citizens owe them duties of gratitude.

In reality, many citizens would not consent to some or all frontline workers continuing their work even with accurate information. This is sometimes because of xenophobia and/or racism. We might think hypothetical consent is obtained so long as citizens would consent if not xenophobic or racist, because hypothetical consent can be obtained if one would consent were they to hold no wrongful views. For example, if Charles is sexist, and so would not consent to being saved if asked, perhaps Beatrice still respects his autonomy when saving his life. He therefore owes Beatrice gratitude, at least if grateful to be alive.

While the above may be true, it is controversial. This is because forcing individuals to accept life-saving interventions is wrong even if their motives are wrong. A sexist patient is permitted to refuse surgery to avoid having a woman conduct the surgery. If he is forced to accept this surgery, he is wronged, and so perhaps owes no gratitude. Hypothetical consent may work similarly, and a patient would owe no gratitude if the doctor performed surgery despite knowing he would have objected for wrongful reasons. Citizens who have objectionable xenophobia may be blameworthy, and perhaps undocumented workers ought to be given visas if undocumented because of xenophobia, but they are not owed permanent residency by virtue of citizens autonomously benefiting.

The above logic is clearer when citizens' motives are not objectionable. Imagine increases in undocumented workers cause spikes in rental prices, and citizens prefer to adopt increased risks than suffer higher rental prices. Their views could be nonwrongful and autonomously derived, such that migrant workers are not providing citizens an autonomous benefit. Autonomous benefits, therefore, cannot explain why citizens owe such workers gratitude.

This leads to a question: whether autonomous benefits are always necessary for owing gratitude. While protecting autonomy may be part of a jointly sufficient set of conditions for gratitude $-\mathrm{X}$ owes gratitude to $\mathrm{Y}$ if $\mathrm{Y}$ assumes supererogatory risks for him and his autonomy is respected-perhaps autonomy is not necessary when a benefactor cannot know what a beneficiary would consent to if asked. If Charles would not have consented to Beatrice saving her life, but she cannot know this fact, she may not actually protect his autonomy, but in saving his life she nonculpably responds to what she reasonably thinks he wants. Charles has good reason to show her gratitude, given that she demonstrated concern for his welfare without intentionally usurping his autonomy. At least, he has good reason to show her gratitude if he is grateful to be alive. Many frontline workers likely do not know what citizens would want, especially during an emergency before polls have been conducted. If they reasonably presume citizens want frontline migrants to continue their work, then even if they do not actually respect the autonomy of citizens, they do the best they can. Gratitude may therefore still be owed, and with it permanent residency.

In contrast, if migrants can reasonably know that fully informed citizens would not consent to their work if asked, such migrants' grounds for gratitude are more ambiguous. This is consistent with the claim that such migrants have other grounds for permanent residency, derived from alternative values.

\section{THREE ALTERNATIVE VALUES}

This section presents the values of reciprocity, membership, and equality as grounding rights to permanent residency. The latter two values explain why many frontline workers not owed gratitude are owed permanent residency. Some might suppose these two values justify permanent residency for all frontline workers. I demonstrate this is not the case; a full account of rights for frontline workers must appeal to gratitude alongside alternative values. 


\section{Reciprocity}

It is commonly claimed that if someone has contributed to society through taxes and interactions with others, she has a reciprocal claim to reap benefits in return (Rubio-Marin 2000; Shachar 2009; Song 2018). This is because of a broader principle of "fair play": it is only fair that those contributing to a cooperative scheme reap benefits from this scheme, even if many who benefit have not consented (Song 2018). This seems particularly true when contributions entail risks. As noted by Michael J Sullivan, migrants accepting burdens can be owed compensation (Sullivan 2019, 19), with those risking their lives-such as soldiersengaging in acts that are particularly burdensome, and so particularly deserving of permanent residency. ${ }^{7}$ Frontline workers might similarly have grounds to permanent residency in virtue of their contributions and risks, even if lacking citizens' hypothetical consent.

The above argument, however, rests on a shaky premise; duties of reciprocity might not be owed for benefits one never consented to obtain. This skepticism is shared by Sullivan, who argues that contributions from unauthorized migrants are not grounds for permanent residency without the consent of a special "community sentencing board" (Sullivan 2019, $24,31)$. In contrast, the gratitude-based argument explains why many unauthorized migrants ought to be given permanent residency even if lacking citizens' consent: sometimes we can owe gratitude to individuals even if we never explicitly consented to their help. In this sense, the reciprocity-based argument fails to expand the set of frontline workers owed permanent residency beyond those owed gratitude, and may capture a narrower set of workers.

\section{Membership}

A second alternative argument appeals to "social membership": with time migrants integrate into society, building valuable relationships that can only be sustained with the right to remain permanently (Carens 2013, 103; Song 2018, 186-8). While time is sufficient for social membership, it might not be necessary for some. For example, the French government permits members of the French Foreign Legion (FFL) - a military unit that recruits foreign nationals - to obtain French citizenship after only three years (Ferrillo 2012). This policy could be justified because recruits demonstrate strong ties to fellow recruits, including French citizens, in shorter amounts of time. If strong ties in shorter amounts of time ground permanent residency rights, perhaps most citizens' consent is unnecessary for permanent residency rights. For example, caretakers during COVID-19 may have strong relationships with those they assist from remaining in their homes throughout the pandemic, and some hospital technicians might gain deep ties with

\footnotetext{
${ }^{7}$ This reasoning provides justification for the former US policy of granting permanent residency to unauthorized migrants joining the military (Sullivan 2019).
}

coworkers, regardless of whether citizens consent to risks technicians assume. Importantly, such ties could emerge even among workers admitting to taking nonobligatory risks solely to avoid life-threatening destitution, and so not owed gratitude.

We might make similar claims about frontline workers without deep interpersonal relationships, but with ties of trust between themselves and citizens they never meet. Broader studies find that those saving others can be heralded as trusted members by the community (Hardie and Critchly 2008), and many citizens seem to feel this way about frontline workers, expressing solidarity with nurses, cleaners, and doctors (Morrison 2020). If this is evidence of valuable ties between citizens and frontline workers, frontline workers have membership-based grounds for permanent residency.

A second membership-based argument leads to similar conclusions. According to Ayelet Shachar and Ran Hirschl, some workers have "social connectedness" (Shachar 2009; Shachar and Hirschl 2014), becoming interdependent with state structures (Shachar 2009, 168-71). For example, a person might depend on streets to commute and pay taxes contributing to streets. The longer a person lives in a country, the more such interdependence constitutes a political relationship with citizens, encouraging the person to value the common good, generating a right to citizenship (Shachar and Hirschl 2014, 250). Frontline workers in the country for a short time might highly depend on state infrastructure to work, as when delivery drivers depend on roads and are depended upon by citizens to decrease the virus's spread. When such interdependence indicates they are committed to the common good, they have grounds for remaining permanently even if most citizens would not consent to their work.

While membership-based arguments ground permanent residency for many frontline workers not owed gratitude, they do not capture all frontline workers. Some lack close relationships with citizens or commitments to the common good, but have gratitude-based grounds to remain. Such might be the case for a doctor without concern for those she helps or close ties with others, but who freely assumes supererogatory risks with citizens' hypothetical consent.

Moreover, membership-based arguments struggle to justify permanent residency for workers taking risks to avoid being fired and destitute, never claiming otherwise. Such workers are neither owed gratitude nor necessarily expressing commitments to the common good, some marginalized from society and so holding no ties with citizens. If such workers still have rights to remain, it is because they experience inequality and exploitation.

\section{Inequality and Exploitation}

This argument begins with a broad premise concerning inequality: inequality is often unjust, though precisely when is up for debate. Luck Egalitarians claim inequality is unjust when some are worse off due to brute luck (Dworkin 2002; Segall 2013). Sufficientarians claim that 
inequality is unjust whenever some cannot live sufficiently decent lives (Axelsen and Nielsen 2015; Huseby 2020). Prioritarians claim that inequality is unjust when resources are distributed merely to maximize aggregate benefits, because benefits ought to count for more the worse off an agent is (Parfit 2012; Peterson and Hansson 2005). Relational Egalitarians hold that inequality is unjust when creating unequal relationships, as when the wealthy dominate the poor (Anderson 1999).

These are simplistic summaries of prominent views, and there are more, but assuming inequality is clearly unjust when all of the above principles are violated, many frontline workers lacking gratitude-based grounds have their rights violated. Those paid little and lacking protective equipment can suffer from anxiety incompatible with a sufficiently decent life (Spoorthy, Pratapa, and Mahantc 2020). If transferring resources to such workers would improve their lives, their circumstances are likely incompatible with Prioritarianism as well. Luck Egalitarianism is violated when frontline workers in low-pay industries cannot easily switch professions because of lower educational attainment (Rho, Brown, and Fremstad 2020), given that poverty in one's youth - for which one usually lacks control-can be an obstacle to educational attainment (Stumm et al. 2020). Violations of Relational Egalitarianism are also rife, with many frontline care workers facing abuse (Doward 2019) and an inability to legally change employment, further restricting their agency vis-à-vis employers (Isaac and Elrick 2020).

In facing unjust inequality, many frontline workers experience a related wrong: that of exploitation. While there is disagreement over when exploitation occurs, it is widely accepted that victims of unjust inequality can become victims of unjust exploitation if others benefit from the inequality they experience. For example, one prominent view of exploitation holds that agents exploit others if benefiting more than they would have, had resources been fairly distributed (Roemer 2013). Another view holds that agents exploit others if benefiting excessively from "outrageous and lopsided terms of exchange" that others accept because they have no reasonable alternatives (Valdman 2009). Frontline workers are likely victims of exploitation according to both views, if accepting nonmorally obligatory risks because they lack reasonable alternatives, due to unjust inequality, resulting in citizens benefiting from reduced risks.

When migrants suffer from wrongful inequality and exploitation, permanent residency is an effective way of mitigating this inequality and exploitation (Berg 2016; Lenard and Straehle 2010; Walzer 1983). As Walzer argued over three decades ago, many temporary workers performing "socially necessary work" are dominated by laws they have no control over, and permanent residency and citizenship can counter this domination (Walzer 1983, 60). If this is true in general, it is true for frontline workers in particular, including thoseindeed especially those - who are clearly taking risks solely to avoid life-threatening unemployment. An individual fruit picker who admits to taking risks solely to access necessities, which she cannot legally access in alternative employment, is dominated by laws she has no control over, while providing benefits for citizens. Such benefits indicate that she is unjustly exploited, and such exploitation can be mitigated if she is given the right to change employment without fear of deportation, the right to protest her position, and welfare provisions should she find herself unemployed. These are basic tenets of permanent residency, as defined in the second section, and so she ought to be granted permanent residency.

This argument may also justify permanent residency for exploited unauthorized workers lacking hypothetical consent from most citizens. Assuming states have a duty to counter gross exploitation even when most citizens have not consented to such exploitation, and permanent residency can counter exploitation, such workers have grounds for permanent residency.

While the above arguments justify permanent residency for many frontline workers, they do not capture residency rights for all frontline workers. A doctor not subject to wrongful exploitation or inequality should still be shown gratitude for her supererogatory risks, and so should still be given permanent residency.

The gratitude-based argument additionally explains why some workers' grounds to remain are overdetermined, because they face inequality and are owed gratitude. A nurse may be fired and destitute if she refuses to take undue risks, but is assuming risks not because of this threat, merely wishing to help others. Some might claim she is not exploited, given that she provides benefits not because she is threatened with destitution, but she is still subject to wrongful inequality via the threat she faces. She is additionally owed gratitude, given that she is assuming nonmorally obligatory risks in order to help others. She therefore has both inequality and gratitude-based grounds to remain.

\section{BEYOND COVID-19}

While principles of membership, equality, and nonexploitation have garnered widespread attention in discussions on immigration, principles of gratitude have been largely neglected. Yet, gratitude is relevant beyond COVID-19. Many workers benefit citizens via supererogatory risks, and so perhaps many have gratitudebased grounds for permanent residency.

This is uncontroversial for some workers. Migrants in the military are already granted permanent residency in a range of countries after serving a minimal number of years (Sullivan 2019), with France waiving any time requirement for FFL soldiers injured in battle (Ferrillo 2012). Assuming many injured have taken supererogatory risks, this policy could be justified on gratitudebased grounds. Gratitude could also explain France's broader policy of occasionally providing citizenship to individuals participating in life-risking acts of kindness, as when a Malian man climbed a building to save a child dangling from a fourth-floor balcony (Vandoorne, Breech, and Westcott 2018). In this sense, the case for granting permanent residency to frontline workers is a 
case for expanding gratitude-based residency beyond soldiers and those engaging in random acts of kindness. ${ }^{8}$

The case can be expanded to include additional migrants. Consider firefighters and health workers participating in long night shifts that reduce life expectancy (Laroche and L'Espérance 2021; Vetter et al. 2016). It may be that many are owed gratitude for assuming supererogatory risks. Nonresidents living abroad may be owed similar gratitude, and sometimes are granted residency rights for this reason. For example, the UK government granted residency to nearly $100,000 \mathrm{Nep}-$ alese soldiers serving as Gurkhas in the UK military (Pariyar 2020), and the US government granted residency to roughly 26,000 Afghan and Iraqi interpreters and their dependents (Radford and Krogstad 2017). If individuals living abroad can be owed gratitude, perhaps even more individuals are owed gratitude-based residency, such as West African health care workers who worked during the Ebola pandemic (WHO 2015), potentially increasing life-expectancy in high-income countries by decreasing the virus's spread.

While many workers are owed gratitude, this needn't imply a duty to grant all such workers permanent residency.

As noted in previous sections, there are limits to costs individuals must bear in showing gratitude, and this applies to groups: when many risk their lives to save many individuals at sea, costs should be allocated fairly between beneficiaries, and if many beneficiaries refuse to cooperate, there is still an upper cost any beneficiary must bear. This has implications for states: a single state may have no duty to grant permanent residency to all owed gratitude-including those abroad-when the costs this imposes are beyond those citizens are obligated to bear. This could be the case if certain employment sectors or public services would be strained. When this occurs, all states with benefiting citizens should cooperate to allocate residency permits to those owed gratitude, limiting costs any states' citizens must bear. When impossible, a given state is still permitted to limit the number given permanent residency if this prevents costs from rising above the obligatory threshold for gratitude. While the threshold is greater than had the state's citizens not benefited, this threshold is still finite.

When limits are justified, this raises the question of who should be prioritized. There are good reasons to prioritize workers living in the country. There are distinct membership-based harms imposed on someone forced to leave a state they are residing in compared with harms imposed on someone denied entrance to a state they have never lived in before. As noted in the last section, frontline workers are interacting regularly with state institutions and often citizens. Given these

\footnotetext{
${ }^{8}$ Of course, many soldiers assume greater risks than many frontline workers, but even soldiers facing lower risks far from the frontlines are granted permanent residency (Sullivan 2019). So long as frontline workers face nonobligatory risks, they have similar grounds to many soldiers.
}

interactions, when subject to deportation, the harm they experience is generally greater than the harm of someone who never lived in the state, all else being equal. If the harm is greater, and the duty of gratitude requires avoiding harm, then the duty to avoid deporting migrants who risked their lives can be generally weightier than the duty to admit nonresidents who risked their lives.

While membership is one central consideration, another is equality. As noted in the last section, an individual can be owed gratitude and face unjust inequality, and the same is true for individuals abroad. An Afghan interpreter risking his life for the US military may face wrongful inequality if denied basic necessities should he refuse his services, but he is still owed gratitude if his motives are solely to help the military. There are good reasons to prioritize him for permanent residency before a doctor working in the US, assuming the doctor faces no unjust inequality. This seems especially true if the interpreter experiences inequality alongside membership claims, holding strong ties with US government institutions via his work.

There is a final consideration, related to what individual policymakers ought to do. Sometimes policymakers prioritizing some individuals legitimizes, amongst citizens, "an adjudication system that is ... unjust to everyone else" (Silverman 2016). For example, US policymakers providing residency to Afghan interpreters may have reinforced the idea that those not taking risks were less deserving of residency rights. The popularity of this idea can constrain policymakers' ability to protect other migrants' rights. More specifically, policymakers granting permanent residency to those owed gratitude, and attempting to respect rights for other migrants, might fail to do so if their attempts quickly cost them reelection. ${ }^{9}$ This worry, articulated by Maike Isaac and Jennifer Elrick when discussing residency rights for COVID-19 workers (2020, 8), is relevant whenever some migrants are deemed more worthy than others.

To establish what ought to be done in such cases, policymakers ought to consider who benefits and who is disadvantaged. If policymakers granting permanent residency to some privileged frontline doctors means they struggle to grant residency to far more refugees, refugees should be prioritized. In contrast, when most granted residency on gratitude-based grounds are also fleeing life-threatening conditions - as is often true for agricultural workers (Markham 2019; Pelek 2019) granting permanent residency may be acceptable even if this makes resettling a smaller number of refugees more difficult.

Moreover, it may be justified to grant permanent residency to a set of frontline workers when this improves citizens' general attitudes toward migrants. This effect may arise during COVID-19, if COVID-19 is what Bonnie Honig calls a "transformative" emergency, in the sense of encouraging support for

\footnotetext{
${ }^{9}$ Political parties may also constrain policymakers' actions (Hampshire 2013).
} 
experimentation and change (Honig 2014, 52). Historically, such experimentation and change has expanded the set of individuals given citizenship-associated rights beyond those owed gratitude, when citizens viewed the emergency as an opportunity to protect democracy and equality (Davenport et al. 2019). For example, the postWWI UK government extended the franchise to all men to show gratitude for fighting in the war (Gottlieb and Toye 2013), but later expanded the franchise to women in 1928. More directly related to migration, post-WWII Canada extended rights to Chinese immigrants on similar grounds of having fought in the war, expanding rights to far more migrants by 1962 (Roy 2011). There is some evidence that COVID-19 can expand the provision of rights to far more migrants. According to Isaac and Elrick, COVID-19 has heightened awareness of migrants' general contributions, with resistance to calling agricultural workers "low skilled" (Isaac and Elrick 2020). If the pandemic has shifted perceptions of what "skilled" means, popularizing the idea that many migrants are owed gratitude-beyond those assuming risks during the pandemic-perhaps permanent residency to frontline workers will help rather than harm the status of other migrants. Establishing if this is true requires empirical research, but such research is essential precisely because of the value of gratitude at stake.

\section{CONCLUSION}

This article presented the case for granting permanent residency to frontline workers, appealing not only to traditional values of membership, equality, and nonexploitation, but to the value of gratitude. Gratitude is additionally owed to other workers at home and abroad, though limiting the number granted gratitude-based rights is justified when costs are sufficiently high. In such cases, states ought to prioritize those residing within the state and victims of gross inequality.

Though gratitude-based claims are narrowed by cost-related considerations, this value still has broad implications. Philosophers have traditionally focused on migrants integrating and contributing to society, rather than risks they assume. While risks are evoked for refugees - those experiencing risks at home need asylum abroad (Brock 2020; Carens 2013; Pevnick 2011; Song 2018) - risks are not only relevant for those fleeing wars, famine, and poverty. They are additionally relevant for those assuming risks while benefiting citizens. Accounting for such benefits expands the range of considerations for immigration policies, and it highlights the ways that migrants are not merely passive actors in need, but active agents providing for citizens' needs.

Of course, focusing on citizens' needs is not entirely new; many countries grant permanent residency to migrants who sacrifice for their adopted country. However, the migrants granted such residency are limited to soldiers, interpreters, and a Malian refugee saving a child dangling from a building. Far more individuals have grounds to remain due to dangers previously overlooked. COVID-19 magnified these dangers, demonstrating what is owed to those participating in acts not traditionally deemed heroic. This focus on seemingly unheroic acts broadens the debate, demonstrating that migrants are wronged not only when their migration status poses risks to themselves, but when they are denied gratitude for assuming risks for others.

\section{ACKNOWLEDGMENTS}

For written comments, a special thanks to David Axelsen, Ava Ayers, Paul Bou-Habib, James Christensen, Dominik Duell, Richard Healey, Patrick Lown, Kieran Oberman, Stephanie Silverman, and four anonymous reviewers. I also thank audiences at the University of Manchester, the University of Oxford, and an online workshop entitled "Normative Theories of Immigration in Times of Covid-19."

\section{FUNDING STATEMENT}

This research was supported by a British Academy/ Leverhulme Small Research Grant (SRG1920\101032).

\section{CONFLICT OF INTEREST}

The author declares no ethical issues or conflicts of interest in this research.

\section{ETHICAL STANDARDS}

The author affirms that this research did not involve human subjects.

\section{REFERENCES}

Anderson, Elizabeth. 1999. "What is the Point of Equality?" Ethics 109 (5): 287-337.

Augère-Granier, Marie-Laure. 2021. "Migrant Seasonal Workers in the European Agricultural Sector." Briefing. EU: European Parliamentary Research Service. https://www.europarl.europa.eu/ RegData/etudes/BRIE/2021/689347/EPRS_BRI(2021)689347_ EN.pdf.

Axelsen, David V., and Lasse Nielsen. 2015. "Sufficiency as Freedom from Duress." The Journal of Political Philosophy 23 (4): 406-26.

Ballinger, Steve. 2020. "Immigration Bill: COVID-19 Boosts Public Support for Low-Paid Frontline Workers.” Accessed July 22, 2020. https://www.britishfuture.org/immigration-bill-covid-19-boostspublic-support-for-low-paid-frontline-workers/.

Beltran, Cristina. 2009. "Going Public: Hannah Arendt, Immigrant Action, and the Space of Appearance." Political Theory 37 (5): 595-622.

Berg, Laurie. 2016. Migrant Rights at Work: Law's Precariousness at the Intersection of Migration and Labour. London: Routledge.

Brock, Gillian. 2020. Justice for People on the Move: Migration in Challenging Times. Cambridge: Cambridge University Press.

Brock, Gillian. 2002. "Liberal Nationalism versus Cosmopolitanism: Locating the Disputes." Public Affairs Quarterly 16 (4): 307-27. 
Budiman, Abby. 2020. "Key Findings about US Immigrants." Pew Research Center, August 20.

Callahan, Daniel. 1985. "What Do Children Owe Elderly Parents?" The Hastings Center Report 15 (2): 32-7.

Camenisch, Paul. 1981. "Gift and Gratitude in Ethics." The Journal of Religious Ethics 9 (1): 1-34.

Carens, Joseph. 2013. The Ethics of Immigration. Oxford: Oxford University Press.

Collins, Stephanie. 2019. Group Duties: Their Existence and Their Implications for Individuals. Oxford: Oxford University Press.

D’Ignoti, Stefania. 2020. "Italy's Coronavirus Amnesty: Migrant Rights or Economic Self-Interest?" The New Humanitarian 25 May. https://www.thenewhumanitarian.org/feature/2020/05/25/ Italy-coronavirus-migrant-labour.

Davenport, Christine, Håvard Mokleiv Nygård, Hanne Fjelde, and David Armstrong. 2019. "The Consequences of Contention: Understanding the After Effects of Political Conflict and Violence." Annual Review of Political Science 22: 361-77.

DEFRA. 2020a. "Oral Evidence: Labour in the Food Supply Chain HC 231." House of Commons. https://committees.parliament.uk/ oralevidence $/ 869 / \mathrm{html} /$.

DEFRA. 2020b. "Seasonal Agricultural Workers." UK Parliamentary Publications and Records. https:// publications.parliament.uk/pa/cm5801/cmselect/cmenvfru/231/ 23108.htm.

Doward, Jamie. 2019. "Revealed: 6,000 Residential Care Workers Suffer Violent Attacks." The Guardian, June 9. https:// www.theguardian.com/society/2019/jun/09/6000-residential-careworkers-suffer-violent-attacks.

Dudley, Mary Jo. 2020. “These US Industries Can't Work Without Illegal Immigrants." CBS News, January 10, 2020, 3:55p.m. https:/ www.cbsnews.com/news/illegal-immigrants-us-jobs-economyfarm-workers-taxes/.

Dworkin, Ronald. 2002. Sovereign Virtue: The Theory and Practice of Equality. Cambridge, MA: Harvard University Press.

Economic Times. 2020. "Legislation Introduced in US to Give Green Cards to Foreign Nurses, Doctors." Economic Times, Last Updated: May 9, 2020, 01:01 PM IST. Accessed on May 29, 2020. https://economictimes.indiatimes.com/nri/visa-and-immigration/ legislation-introduced-in-us-to-give-greencards-to-foreign-nursesdoctors/articleshow/75640702.cms.

EFRAC. 2020. "The UK's New Immigration Policy and the Food Supply Chain." Environment, Food and Rural Affairs Committee, UK Parliamentary Publications and Records. https:// publications.parliament.uk/pa/cm5801/cmselect/cmenvfru/231/ 23102.htm.

Enoch, David. 2017. "Hypothetical Consent and the Value(s) of Autonomy." Ethics 128 (1): 6-36.

Food and Agriculture Organization of the United Nations (FAO). 2020. "Migrant Workers and the COVID-19 Pandemic." Rome: FAO. https://doi.org/10.4060/ca8559en.

Ferrillo, Raffaele. 2012. "The Management of Ethnic-Cultural Diversity in Western Armed Forces." Technical Report. Carlisle Barracks, PA: Army War College.

Flocks, Joan. 2020. "The Potential Impact of COVID-19 on H-2A Agricultural Workers." Journal of Agromedicine 25 (4): 367-69.

Gloash-Boza, Tanya. 2014. "Forced Transnationalism: Transnational Coping Strategies and Gendered Stigma among Jamaican Deportees." Global Networks 14 (1): 10-1.

Gottlieb, Julie V., and Richard Toye. 2013. The Aftermath of Suffrage: Women, Gender, and Politics in Britain, 1918-1945. Basingstoke, UK: Palgrave Macmillan.

Government of Canada. 2021. "Temporary Public Policies: Temporary Resident to Permanent Resident Pathway: About the Program.” Accessed June 1, 2021. https://www.canada.ca/en/ immigration-refugees-citizenship/services/immigrate-canada/trpr-pathway.html.

Hampshire, James. 2013. The Politics of Immigration: Contradictions of the Liberal State. Cambridge: Polity.

Hardie, Elizabeth A., and Christine R. Critchly. 2008. "Public Perceptions of Australia's Doctor, Hospitals and Health care Systems." Medical Journal of Australia 189 (4): 210-14.

Hartley, Christie. 2014. "Two Conceptions of Justice as Reciprocity." Social Theory and Practice 40 (3): 414-17.
Hellman, Deborah. 2008. When is Discrimination Wrong? Cambridge, MA: Harvard University Press.

Heyd, David. 1982. Supererogation. Cambridge: Cambridge University Press.

Hindriks, Frank. 2018. "Collective Agency: Moral and Amoral." Dialectica 72 (1): 3-23.

Honig, Bonnie. 2014. "Three Models of Emergency Politics." Boundary 241 (2): 45-70.

Hurka, Thomas. 1997. "The Justification of National Partiality." In The Morality of Nationalism, eds. Robert McKim and Jeff McMahan, 140-53. Oxford: Oxford University Press.

Huseby, Robert. 2020. "Sufficiency and the Threshold Question." The Journal of Ethics 24: 207-23.

Isaac, Maike, and Jennifer Elrick. 2020. "How COVID-19 May Alleviate the Multiple Marginalization of Racialized Migrant Workers." Ethnic and Racial Studies 44 (5): 851-63.

Jordan, Miriam. 2020. "Farmworkers, Mostly Undocumented, Become 'Essential' During Pandemic." New York Times, April, 4. https://www.nytimes.com/2020/04/02/us/coronavirusundocumented-immigrant-farmworkers-agriculture.html.

Karnein, Anja. 2014. "Putting Fairness in Its Place: Why There Is a Duty to Take Up the Slack." The Journal of Philosophy 111 (11): 593-607.

Laroche, Elena, and Sylvain L’Espérance. 2021. “Cancer Incidence and Mortality among Fire-Fighters: An Overview of Epidemiologic Systematic Reviews." International Journal of Environmental Research and Public Health 18 (5): 1-37.

Lenard, Patti Tamara, and Christine Straehle. 2010. "Temporary Labour Migration: Exploitation, Tool of Development, or Both?" Policy and Society 29 (4): 283-94.

Lippert-Rasmussen, Kasper. 2014. Born Free and Equal? A Philosophical Inquiry into the Nature of Discrimination. Oxford: Oxford University Press.

Lister, Matthew. 2020. "Enforcing Immigration Law." Philosophy Compass 15 (3): 1-11.

Logue, Jennifer K., Nicholas M Franko, Denise J McCulloch, Dylan McDonald, Ariana Magedson, Caitlin R Wolf, and Helen Y Chu. 2021. "Sequelae in Adults at 6 Months after COVID-19 Infection." JAMA Network Open 4 (2): 1-4.

Manela, Tony. 2015. "Obligations of Gratitude and Correlative rights." Oxford Studies in Normative Ethics 5: 151-70.

Markham, Lauren. 2019. "How Climate Change is Pushing Central American Migrants to the US." The Guardian, April 6. https:// www.theguardian.com/commentisfree/2019/apr/06/us-mexicoimmigration-climate-change-migration.

McConnell, Terrance. 2017. "Gratitude, Rights, and Moral Standouts." Ethical Theory and Moral Practice 20 (2): 279-93.

Méheut, Constant. 2020. "They Helped France Fight the Virus. Now France Is Fast-Tracking Their Citizenship." New York Times, December 22. https://www.nytimes.com/2020/12/22/world/europe/ france-naturalization-covid-frontline.html.

Moore, Margaret. 2009. "Is Patriotism an Associative Duty?" The Journal of Ethics 13 (4): 383-99.

Moran, Layla. 2020. "All Key Workers from Overseas Should be Granted Indefinite Leave to Remain -It's The Least We Can Do." Huffington Post, April 7. https://www.huffingtonpost.co.uk/ entry/coronavirus-key-workers-nhs-indefinite-leave_uk_ 5 e8b440ec5b6cbaf282d1132.

Morrison, Anoushka. 2020. "Creativity in Lockdown: Finding New Ways to Support Families." The Frontline, May 15. https:// thefrontline.org.uk/creativityin-lockdown-finding-new-ways-tosupport-families/.

Painter, Kim. 2020. "Work Visas: Foreign Doctors in the US Have More Than COVID-19 to Fear." BMJ 370: 1-2.

Parfit, Derek. 2012. "Another Defense of the Priority View." Utilitas 24 (3): 399-440.

Pariyar, Mitra. 2020. "Caste, Military, Migration: Nepali Gurkha Communities in Britain." Ethnicities 20 (3): 608-27.

Pelek, Deniz. 2019. "Syrian Refugees as Seasonal Migrant Workers: Re-construction of Unequal Power Relations in Turkish Agriculture." Journal of Refugee Studies 32 (4): 605-29.

Peterson, Martin, and Ove Hansson. 2005. "Equality and Priority." Utilitas 17 (3): 299-309. 
Pevnick, Ryan. 2011. Immigration and the Constraints of Justice: Between Open Borders and Absolute Sovereignty. Cambridge: Cambridge University Press.

Quong, Jonathan. 2010. Liberalism without Perfection. Oxford: Oxford University Press.

Radford, Jynnah, and Jens Manuel Krogstad. 2017. "Afghans Who Worked for US Government Make Up Growing Share of Special Immigrant Visa Recipients." Pew Research Center, December.

Raz, Joseph. 1988. The Morality of Freedom. Oxford: Oxford University Press.

Rho, Hye Jin, Hayley Brown, and Shawn Fremstad. 2020. "A Basic Demographic Profile of Workers in Frontline Industries." Center for Economic and Policy Research, April 7. Accessed on August 10, 2020. https://cepr.net/wp-content/uploads/2020/04/2020-04Frontline-Workers.pdf.

Roemer, John E. 2013. A General Theory of Exploitation and Class. Cambridge, MA: Harvard University Press.

Roy, Patricia E. 2011. The Triumph of Citizenship: The Japanese and Chinese in Canada, 1941-67. Vancouver, CA: UBC Press.

Rubio-Marin, Ruth. 2000. Immigration as a Democratic Challenge: Citizenship Inclusion in Germany and the United States. Cambridge: Cambridge University Press.

Sager, Alex. 2017. "Immigration Enforcement and Domination: An Indirect Argument for Much More Open Borders." Political Research Quarterly 70 (1): 42-54.

Segall, Shlomi. 2013. Equality and Opportunity. Oxford: Oxford University Press.

Seglow, Jonathan. 2013. Defending Associative Duties. New York: Routledge.

Shachar, Ayelet. 2009. The Birthright Lottery: Citizenship and Global Inequality. Cambridge, MA: Harvard University Press.

Shachar, Ayelet, and Ran Hirschl. 2014. "On Citizenship, States, and Markets." Journal of Political Philosophy 22 (2): 231-57.

Siddique, Haroon. 2020. "Give Foreign Nationals in NHS Indefinite Leave to Remain, say MPs." The Guardian, April 7. https:// www.theguardian.com/uk-news/2020/apr/07/foreign-nationalsnhs-indefinite-leave-remain-coronaviruscovid-19.

Silverman, Stephanie J. 2016. "'Imposter-Children' in the UK Refugee Status Determination Process." Refuge: Canada's Journal on Refugees 32 (3): 30-9.

Simmons, A. John. 1981. Moral Principles and Political Obligations. Princeton, NJ: Princeton University Press.

Song, Sarah. 2018. Immigration and Democracy. Oxford: Oxford University Press.
Spoorthy, Mamidipalli Sai, Sree Karthik Pratapa, and Supriya Mahantc. 2020. "Mental Health Problems Faced by Health Care Workers Due to the COVID-19 Pandemic: A Review." Asian Journal of Psychiatry 51: 1-4.

Stemplowska, Zofia. 2016. "Doing More Than One's Fair Share." Critical Review of International Social and Political Philosophy 19 (5): 591-608

von Stumm, Sophie, Emily Smith-Woolley, Ziada Ayorech, Andrew McMillan, Kaili Rimfeld, Philip S. Dale, and Robert Plomin. 2020. "Predicting Educational Achievement from Genomic Measures and Socioeconomic Status." Developmental Science 23 (3): 1-8.

Sullivan, Michael J. 2019. Earned Citizenship. Oxford: Oxford University Press.

Sumption, Madeleine, and Denis Kierans. 2019. "Work Visas and Migrant Workers in the UK." The Migration Observatory. Oxford, UK: Centre on Migration, Policy and Society.

Tadros, Victor. 2016. Wrongs and Crimes. Oxford: Oxford University Press.

Terrance, McConnell. 1993. Gratitude. Philadelphia, PA: Temple University Press.

Valdman, Mikhail. 2009. "A Theory of Wrongful Exploitation." Philosopher's Imprint 9 (6): 1-14.

Vandoorne, Saskya, Samantha Beech, and Ben Westcott. 2018. “'Spiderman' Granted French Citizenship after Rescuing Child from Paris Balcony." CNN, May 28, 2018. Accessed July 23, 2020 https://edition.cnn.com/2018/05/28/asia/paris-baby-spidermanrescue-intl/index.html.

Vetter, Céline, Elizabeth E Devore, Lani R Wegrzyn, Jennifer Massa, Frank E Speizer, Ichiro Kawachi, Bernard Rosner, Meir J Stampfer, and Eva S Schernhammer. 2016. "Association between Rotating Night Shift Work and Risk of Coronary Heart Disease among Women." JAMA 315 (16): 1726-34.

Villarejo, Don. 2020. "Increased Risks and Fewer Jobs: Evidence of California Farmworker Vulnerability during the COVID-19 Pandemic." CIRS Research Report. San Francisco: California Institute for Rural Studies.

Von Tevenar, Gudrun. 2006. "Gratitude, Reciprocity, and Need." American Philosophical Quarterly 43 (2): 181-88.

Walker, ADM. 1980. "Gratefulness and Gratitude." Proceedings of the Aristotelian Society 81 (1): 39-55.

Walzer, Michael. 1983. Spheres of Justice: A Defense of Pluralism and Equality. New York: Basic Books.

WHO. 2015. "Health Worker Ebola Infections in Guinea, Liberia and Sierra Leone: A Preliminary Report.” Technical Report. World Health Organization. 